\title{
Induction of Apoptotic Effects of Antiproliferative Protein from the Seeds of Borreria hispida on Lung Cancer (A549) and Cervical Cancer (HeLa) Cell Lines
}

\author{
S. Rupachandra and D. V. L. Sarada \\ Department of Biotechnology, School of Bioengineering, SRM University, Kattankulathur 603203, India \\ Correspondence should be addressed to D. V. L. Sarada; sarada.dvl@ktr.srmuniv.ac.in
}

Received 25 July 2013; Revised 8 December 2013; Accepted 10 December 2013; Published 30 January 2014

Academic Editor: Stelvio M. Bandiera

Copyright (C) 2014 S. Rupachandra and D. V. L. Sarada. This is an open access article distributed under the Creative Commons Attribution License, which permits unrestricted use, distribution, and reproduction in any medium, provided the original work is properly cited.

\begin{abstract}
A $35 \mathrm{KDa}$ protein referred to as F3 was purified from the seeds of Borreria hispida by precipitation with $80 \%$ ammonium sulphate and gel filtration on Sephadex G-100 column. RP-HPLC analysis of protein fraction (F3) on an analytical C-18 column produced a single peak, detected at $220 \mathrm{~nm}$. F3 showed an apparent molecular weight of $35 \mathrm{KDa}$ by SDS PAGE and MALDI-TOF-MS analyses. Peptide mass fingerprinting analysis of F3 showed the closest homology with the sequence of 1-aminocyclopropane-1-carboxylate deaminase of Pyrococcus horikoshii. The protein (F3) exhibited significant cytotoxic activity against lung (A549) and cervical (HeLa) cancer cells in a dose-dependent manner at concentrations ranging from $10 \mu \mathrm{g}$ to $1000 \mu \mathrm{g} / \mathrm{mL}$, as revealed by the MTT assay. Cell cycle analysis revealed the increased growth of sub-G0 population in both cell lines exposed to a concentration of $1000 \mu \mathrm{g} / \mathrm{mL}$ of protein fraction F3 as examined from flow cytometry. This is the first report of a protein from the seeds of Borreria hispida with antiproliferative and apoptotic activity in lung (A549) and cervical (HeLa) cancer cells.
\end{abstract}

\section{Introduction}

Cancer is the largest single cause of death in men and women, and chemoprevention has been a promising anticancer approach aimed at reducing the morbidity and mortality of cancer by delaying the process of carcinogenesis. Among many recent advances in cancer chemotherapy, plant natural products play an important role in having contributed considerably to approximately $60 \%$ of available cancer chemotherapeutic drugs [1]. A new strategy in cancer therapy is to induce the apoptosis in tumor cells which is characterized by early activation of endogenous proteases, cell shrinkage, membrane blebbing, and DNA fragmentation [2].

Plant-derived compounds and their semisynthetic and synthetic analogs serve as major source of pharmaceuticals for human diseases [3]. One of the most active areas of research in the field of cancer therapy is the search for plant proteins with potent cytotoxic activity and low toxicity with varied mechanisms of action on tumors. Plant seeds are an enormously rich source of proteins with the potential to be developed as anticancer agents, for example, Violaceae [4], Rubiaceae [5], and Cucurbitaceae [6] families and certain marine plants [7].

B. hispida (Rubiaceae) is a promising medicinal plant which is widely used in folk medicine to treat fever due to primary complex, ulcer, and glandular swellings [8]. Ethnobotanically, B. hispida has been used as therapeutic agent in the treatment of various pathological conditions. It is used as an antieczemic and antibacterial and also used to treat cardiovascular disorders $[9,10]$. The methanolic extract of seeds of $B$. hispida inhibited the growth of human lung carcinoma (A549) and breast carcinoma (MCF-7) cell lines [11]. The aim of this study is to isolate and purify the proteins exhibiting cytotoxic activity from the seeds of Borreria hispida. The significant effect of purified protein on cell proliferation and cell cycle arrest of lung (A549) and cervical (HeLa) cancer cell lines is also investigated. 


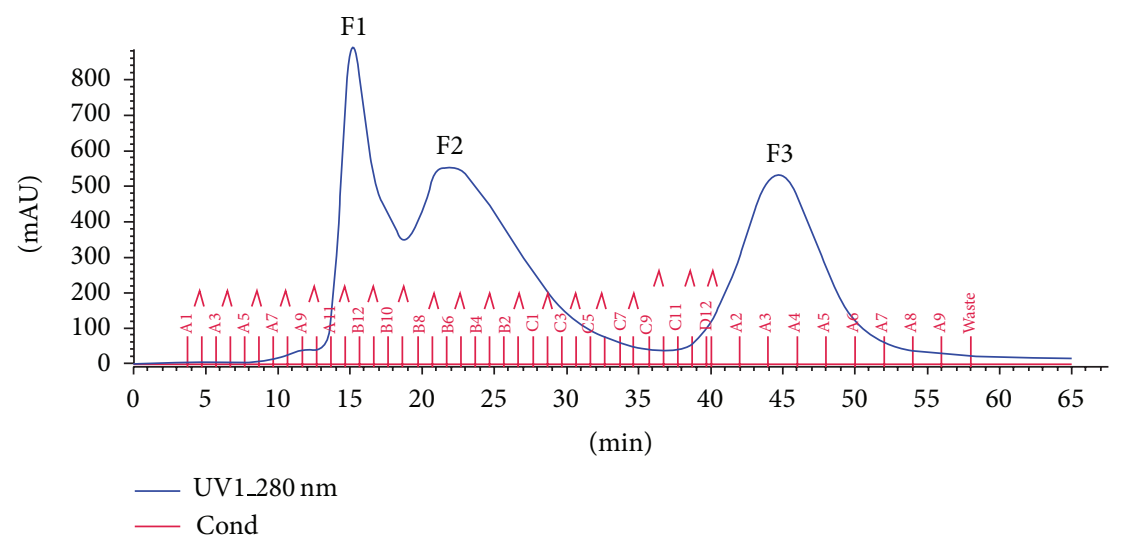

FIGURE 1: Size exclusion (Sephadex G-100) chromatogram of the protein fractions obtained from $80 \%$ ammonium sulphate precipitation from the seeds of B. hispida.

\section{Experimental}

2.1. Materials. Seeds of B. hispida were collected and authenticated from the Plant Anatomy Research Centre, Chennai. All the reagents and chemicals were purchased from Sigma Aldrich. Buffers used for FPLC analysis were of analytical grade. Tumour cell lines, A549 (human lung adenocarcinoma epithelial cell line), and HeLa (human cervical adenocarcinoma epithelial cell line) were purchased from NCCS, Pune.

2.2. Protein Extraction. Seeds of B. hispida were washed with distilled water and shade dried. The dried seeds were ground to fine powder and the proteins were extracted with extraction buffer [12] consisting of $10 \mathrm{mM} \mathrm{Na}_{2} \mathrm{HPO}_{4}$, $15 \mathrm{mM} \mathrm{NaH} \mathrm{PO}_{4}, 10 \mathrm{mM} \mathrm{KCl}$, and $2 \mathrm{mM}$ EDTA ( $\mathrm{pH} 7.0$ ) by constant stirring overnight at $4^{\circ} \mathrm{C}$. The crude protein extract was filtered using the muslin cloth and centrifuged at $10,000 \mathrm{rpm}$ for 10 minutes. Proteins were precipitated from the crude supernatant using ammonium sulphate up to $80 \%$ saturation, overnight at $4^{\circ} \mathrm{C}$. The precipitated proteins were collected by centrifugation at $12,000 \mathrm{rpm}$ for $20 \mathrm{~min}$. The protein concentration was determined according to Lowry et al. (1951) [13], using bovine serum albumin as standard.

2.3. Purification of Proteins. The precipitated protein fractions obtained by $80 \%$ ammonium sulphate saturation were applied onto Fast Protein Liquid chromatography (Akta purifier GE Healthcare) using Sephadex G-100 gel filtration column $(1.5 \times 50 \mathrm{~cm})$ equilibrated with $50 \mathrm{mM}$ Tris- $\mathrm{HCl}$ buffer $(\mathrm{pH} 7.5)$. The protein fractions were eluted using the same buffer at a flow rate of $0.1 \mathrm{~mL} / \mathrm{min}$ and detected at $280 \mathrm{~nm}$ [14]. $2 \mathrm{~mL}$ fractions were collected and screened for cytotoxic activity against the selected cancer cell lines. The protein fraction exhibiting increased cytotoxic activity warranted further studies.

2.4. RP-HPLC Analysis. The purity of protein fraction F3 which showed potent cytotoxic activity was tested using analytical reverse phase-HPLC- $\mathrm{C}_{18}$ column $(250 \times 4.6 \mathrm{~mm}$, $5 \mu \mathrm{m}, 300 \AA$ ), with solution A being $0.1 \%$ TFA and solution B being acetonitrile (90\%) as the mobile phase at a flow rate of $1 \mathrm{~mL} / \mathrm{min}$, and detected at $220 \mathrm{~nm}$ [15].

2.5. SDS-PAGE Analysis. 12\% SDS-PAGE analysis of active protein fraction $\mathrm{F} 3$ was performed according to Laemmli et al. [16]. About $20 \mu \mathrm{g} / \mathrm{mL}$ of F3 fraction was loaded in Lane 1 (Figure 1) and $20 \mu \mathrm{g} / \mathrm{mL}$ of protein marker with the molecular weight in the range of $14.3 \mathrm{KDa}-66 \mathrm{KDa}$ was loaded in Lane 2. Electrophoresis was run at $100 \mathrm{~V}$ for $2 \mathrm{hrs}$. The protein bands were visualized using Coomassie Brilliant Blue (CBB) R-250 [17].

2.6. Identification of Protein Fraction F3 by MALDI-TOF Mass Spectrometry. The gel band of F3 was excised from SDSPAGE and the tryptic digests were analysed using MALDITOF mass spectrometry which acts as a platform to generate the molecular mass of purified F3 protein [18]. In proteomics research, trypsin is commonly used for protein digestion to produce peptides with molecular masses in the optimal range for MS analysis. Prior to tryptic digestion, purified F3 protein was reduced and alkylated with tributylphosphine (TBP) and $15 \mathrm{mM}$ iodoacetamide, respectively. About $2 \mu \mathrm{g}$ trypsin predissolved in $1 \mathrm{mM} \mathrm{HCl}$ was added to $\mathrm{F} 3$ and digested for $12-$ $18 \mathrm{hr}$ at $37^{\circ} \mathrm{C}$. An equal volume of cyano-4-hydrocinnamic acid solution (10 mg/mL CHCA in $70 \%$ ACN, $0.03 \%$ TFA) was added to the trypsinized protein fraction F3. MALDITOF spectrum depicts the fragmentation of F3 in to various peptides. Peptide mass fingerprinting (PMF) was carried out to examine the sequence of the peptide fragments of F3 using SWISS-PROT sequence database.

2.7. Evaluation of Cytotoxic Activity of Protein Fractions. The isolated protein fractions were tested for cytotoxic activity against lung (A549) and cervical (HeLa) cancer cell lines. A549 and HeLa cells were cultured in Dulbecco's modified eagle medium (GIBCO), supplemented with $10 \%$ fetal bovine serum (GIBCO) and $1 \%$ antibiotic antimycotic solution at $37^{\circ} \mathrm{C}$ in a humidified atmosphere of $5 \% \mathrm{CO}_{2}$. A549 and HeLa cells were separately seeded at densities of 3500 and 3000 cells/well, respectively, in 96-well microtitre plates in 
a total volume of $200 \mu \mathrm{L}$. The protein fractions were added at concentrations ranging from $10 \mu \mathrm{g}$ to $1000 \mu \mathrm{g}$ and cells were incubated. After 24 hours, the cellular morphology was observed using a phase contrast microscope (Leica, Wetzlar, Germany). MTT assay [19] was performed to evaluate the cytotoxic activity of the protein fractions. To each of the wells, $50 \mu \mathrm{L}(5 \mathrm{mg} / \mathrm{mL})$ of $0.5 \%$ MTT was added and incubated for $4 \mathrm{~h}$. The formazan crystals formed were dissolved in dimethyl sulfoxide (DMSO) and the absorbance was read at $570 \mathrm{~nm}$ using a microplate reader (Bio-Rad, CA). Wells without protein fractions served as blank. Doxorubicin (Sigma) was used as positive control. Percentage inhibition of cell viability was determined by using the formula $A_{\text {control }}-A_{\text {treatment }} / A_{\text {control }} \times$ 100 .

2.8. Cell Cycle Analysis by Flow Cytometry. A549 and HeLa cells were separately seeded in 6 -well culture plates at a density of $0.3 \times 10^{6}$ cells/well and allowed to attach to the plates by incubating at $37^{\circ} \mathrm{C}, 5 \% \mathrm{CO}_{2}$ in an incubator for $24 \mathrm{~h}$. The cells were treated with F3 at the concentration of $1000 \mu \mathrm{g} / \mathrm{mL}$ using fresh media and incubated for 24 , and $48 \mathrm{~h}$ for A549 and HeLa cells, respectively. The cells were trypsinized, washed with media, and centrifuged at $1000 \mathrm{rpm}$ for $5 \mathrm{~min}$ at $4^{\circ} \mathrm{C}$. The supernatant was discarded and cells were suspended in $300 \mu \mathrm{L}$ of PBS and $700 \mu \mathrm{L}$ of ethanol. The contents were kept at $4^{\circ} \mathrm{C}$ and then processed for cell cycle analysis by flow cytometry [20]. The cells were washed and centrifuged at $1500 \mathrm{rpm}$ for $10 \mathrm{~min}$ at $4^{\circ} \mathrm{C}$. The supernatant obtained was discarded and cells were resuspended in $600 \mu \mathrm{L}$ of PBS containing $0.5 \%$ Triton X-100 and $20 \mu \mathrm{g}$ RNase and incubated at room temperature for $1 \mathrm{~h}$. To the cells, $24 \mu \mathrm{L}$ $(40 \mu \mathrm{g} / \mathrm{mL})$ of propidium iodide ( $1 \mathrm{mg} / \mathrm{mL}$ stock) was added and again incubated at room temperature for $45 \mathrm{~min}$ in dark. The cells were detected in a flow cytometer (FACSCalibur, Beckton Dickinson) equipped with an air cooled argon laser providing $15 \mathrm{~mW}$ at $488 \mathrm{~nm}$ (blue laser) with standard filter setup. Ten thousand events were acquired and the percentage of cells in each phase of the cell cycle was analyzed using CellQuest Pro software (Becton Dickinson, USA).

2.9. Statistical Analysis. Data for in vitro experiments are expressed as mean \pm S.E.M. Comparisons between treated groups and control were performed with Dunnett's Multiple Comparison Test with $P<.0001, P<0.001$, and $P<0.01$ indicating significant difference compared to the control.

\section{Results and Discussion}

3.1. Protein Extraction and Purification. Purification of the precipitated proteins [21] with Sephadex G-100 gel filtration chromatography (FPLC, Akta, and GE) using Tris $\mathrm{HCl}(\mathrm{pH}$ 7.5) resulted in the elution of protein fractions designated as F1 eluted at $15 \mathrm{~min}, \mathrm{~F} 2$ at $25 \mathrm{~min}$, and F3 at $45 \mathrm{~min}$ detected at $280 \mathrm{~nm}$ (Figure 1). The protein concentration in each fraction was determined according to Lowry et al. (1951). The elution volume of the protein fractions was compared with that of standard molecular weight markers of cytochrome c, $\alpha$-lactalbumin, trypsinogen, ovalbumin and bovine serum

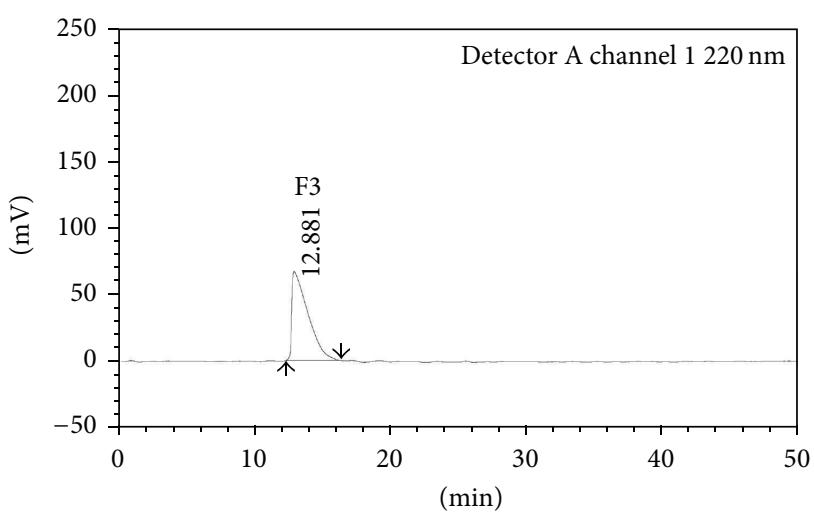

FIGURE 2: Reverse Phase HPLC of protein fraction F3 isolated from seeds of $B$. hispida.

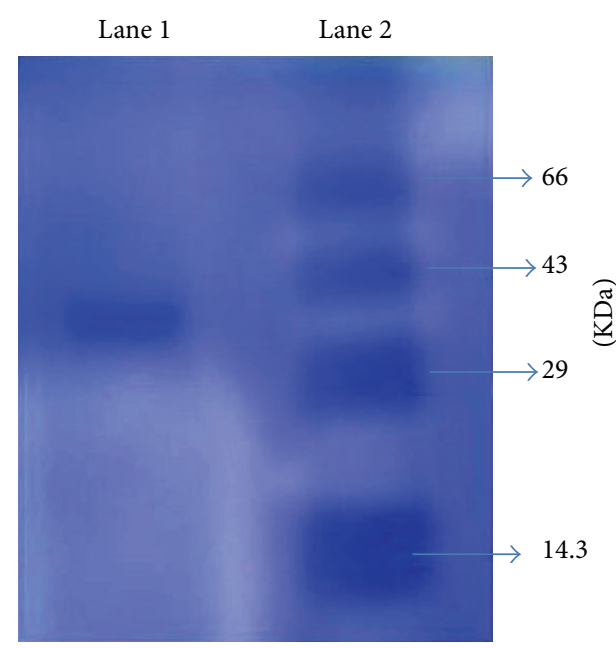

FIGURE 3: SDS-PAGE analysis of protein fraction F3 purified using Sephadex G-100 chromatogtraphy from the seeds of B. hispida. Lane 1: purified protein fraction F3 eluted from FPLC showed a single protein band showing approximate molecular mass of $35 \mathrm{KDa}$. Lane 2: molecular weight marker (range $14.3 \mathrm{KDa}-66 \mathrm{KDa}$ ).

albumin. The results obtained in this study suggested that plant proteins with molecular masses of $4 \mathrm{KDa}-150 \mathrm{KDa}$ can be separated using Sephadex G-100 chromatography [22]. Earlier Etlzer (1985) reported the purification of plant lectins consisting of subunits ranging in molecular mass from $25 \mathrm{KDa}$ to $35 \mathrm{KDa}$ using Sephadex G-100 chromatography [23]. The purified peak fraction eluted at $45 \mathrm{~min}$ was found to possess maximum cytotoxic activity and was named as "protein fraction F3" which was then carried on for further analyses.

3.2. Reverse Phase-HPLC Analysis. RP-HPLC of cytotoxic protein fraction F3 showed a single peak (Figure 2) indicating the presence of single protein with a retention time of $12.8 \mathrm{~min}$ which was detected at $220 \mathrm{~nm}$. In agreement with this result, it is evident that the protein fraction F3 appeared to have $>90 \%$ purity which yields a single band with an apparent molecular mass of $35 \mathrm{KDa}$. 


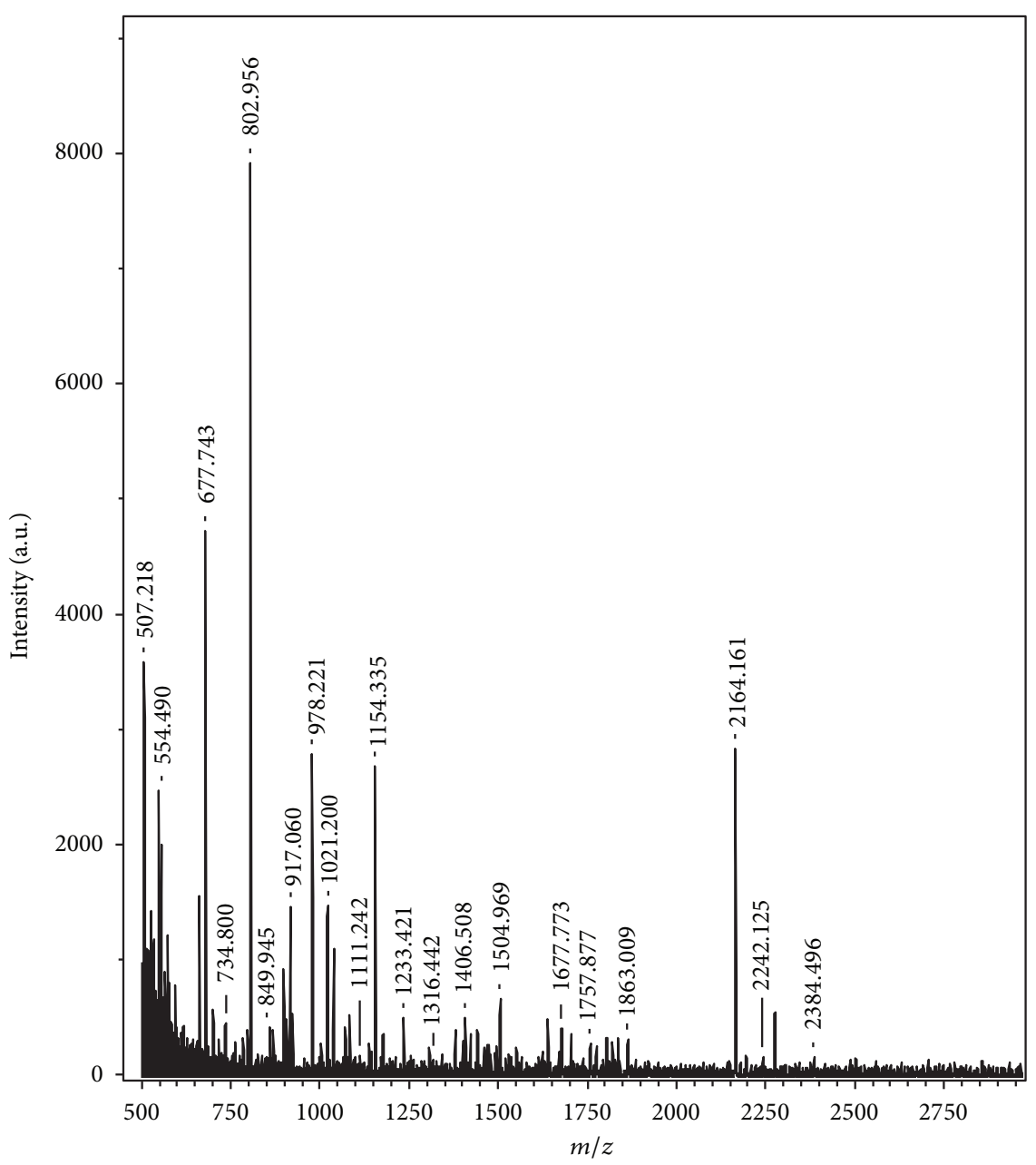

FIgURE 4: MALDI-TOF/MS spectrum of the protein fraction F3.

3.3. Identification of Protein Fraction (F3) by SDS PAGE. The solubilizing denaturing agents such as sodium dodecyl sulphate (SDS) are widely used in the separation of proteins by gel electrophoresis. Identification of approximate mass of the cytotoxic protein fraction F3 was analysed by SDS-PAGE. A single band corresponding to the molecular weight of F3 approximately $35 \mathrm{KDa}$ was observed when compared with the standard molecular weight markers (Figure 3).

3.4. Peptide Mass Fingerprinting of Protein Fraction (F3). Matrix-assisted laser desorption ionization time-of-flight (MALDI-TOF) has become an important tool of choice for large molecular analyses, especially for proteins. The proteome profiling technique by MALDI-TOF-MS provided a broad-base and effective approach for the identification of proteins with biological activity $[24,25]$. In the present investigation the gel band of F3 was excised from Coomassie Blue-stained gel and further processed for MALDI-TOFMS analysis. Each peak in the MALDI-TOF-MS spectrum as given in Figure 4 represents a peptide present in the tryptic digest of protein fraction F3. The size of the peptide ion varies from $\mathrm{m} / \mathrm{z} 507.21$ to 2384.49 . The most abundant peptide ions are $m / z 677.74,802.95,978.22,1154.33$, and 2164.16 as given in Figure 4. The nominal mass of the active protein F3 was found to be $35166 \mathrm{Da}$ as obtained from peptide mass fingerprinting analysis. Identification of F3 using SWISS-PROT database which contains theoretical tryptic digests of all known proteins revealed the sequence similarity with 1-325 amino acids of 1-aminocyclopropane1-carboxylatedeaminase (ACCD) of hyperthermophilic archearon, Pyrococcus horikoshii OT3 (Box 1). The molecular mass of mapped peptides of ACCD with F3 is given in Table 1 . ACCD is a pyridoxal $5^{\prime}$-phosphate dependent enzyme that shows deaminase activity toward ACC, a precursor of plant hormone ethylene. ACCD has been reported to break the cyclopropane ring of ACC to yield $\alpha$-ketobutyrate and ammonia [26].

3.5. Cytotoxic Effect of Protein Fractions on Lung (A549) and Cervical (HeLa) Cancer Cells. Cultured cancer cells are valuable reagents not only for rapid screening of potential anticancer agents but also for elucidation of mechanism of their activity. In this study, cytotoxic activity of purified protein fractions was determined using MTT assay on 


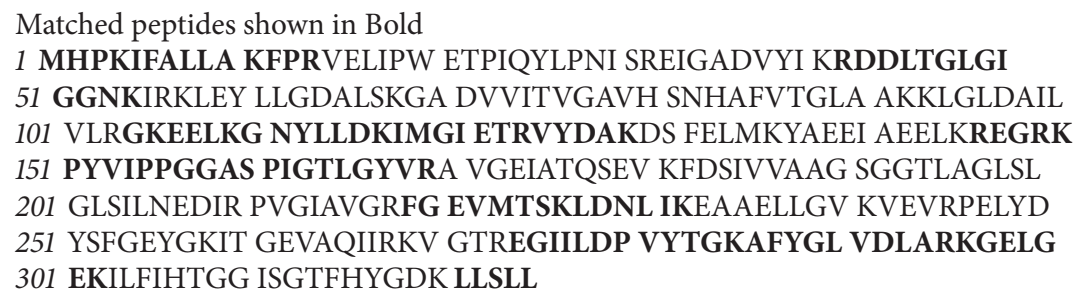

Box 1: Peptide mass fingerprinting analysis of protein fraction F3 showed sequence similarity (shown in bold) with amino acid sequences of 1-aminocyclopropane-1-carboxylate deaminase (1-325) of Pyrococcus horikoshii OT3 identified from SWISS-PROT database.

TABLE 1: The molecular mass of peptides and their aminoacid sequences (1-325 aminoacids) of 1-aminocyclopropane-1-carboxylate deaminase of Pyrococcus horikoshii OT3.

\begin{tabular}{|c|c|c|c|c|c|c|}
\hline Start-end & Observed & $\mathrm{Mr}(\operatorname{expt})$ & $\mathrm{Mr}$ (calc) & Delta & Miss & Sequence \\
\hline $1-4$ & 511.2710 & 510.2637 & 511.2577 & -0.9940 & 0 & -.MHPK.I \\
\hline $1-4$ & 512.2440 & 511.2367 & 511.2577 & -0.0210 & 0 & -.MHPK.I \\
\hline $1-4$ & 513.2960 & 512.2887 & 511.2577 & 1.0310 & 0 & -.MHPK.I \\
\hline $1-4$ & 527.3730 & 526.3657 & 527.2526 & -0.8869 & 0 & -.MHPK.I (M) \\
\hline $1-4$ & 529.3150 & 528.3077 & 527.2526 & 1.0551 & 0 & -.MHPK.I (M) \\
\hline $1-11$ & 1284.54 & 1283.533 & 1283.7424 & -0.2086 & 1 & -.MHPKIFALLAK.F (M) \\
\hline $2-11$ & 1138.289 & 1137.2817 & 1136.7070 & 0.5748 & 1 & M.HPKIFALLAK.F \\
\hline $5-14$ & 1176.308 & 1175.3007 & 1174.7226 & 0.5781 & 1 & K.IFALLAKFPR.V \\
\hline $42-54$ & 1316.44 & 1315.4347 & 1314.6892 & 0.7455 & 1 & K.RDDLTGLGIGGNK.I \\
\hline $104-109$ & 703.71 & 702.7087 & 702.3912 & 0.3175 & 1 & R.GKEELK.G \\
\hline $106-109$ & 519.355 & 518.3477 & 517.2748 & 1.0730 & 0 & K.EELK.G \\
\hline $110-123$ & 1639.799 & 1638.7917 & 1637.8447 & 0.9471 & 1 & K.GNYLLDKIMGIETR.V (M) \\
\hline $124-128$ & 594.397 & 593.3897 & 594.3013 & -0.9116 & 0 & R.VYDAK.D \\
\hline $146-149$ & 516.345 & 515.3377 & 516.2768 & -0.9391 & 1 & K.REGR.K \\
\hline $146-149$ & 517.331 & 516.3237 & 516.2768 & 0.0469 & 1 & K.REGR.K \\
\hline $147-169$ & 2384.49 & 2383.4887 & 2383.3012 & 0.1875 & 1 & R.EGRKPYVIPPGGASPIGTLGYVR.A \\
\hline $219-226$ & 898.02 & 897.0167 & 897.4266 & -0.4099 & 0 & R.FGEVMTSK.L \\
\hline $219-232$ & 1610.62 & 1609.6177 & 1609.8385 & -0.2208 & 1 & R.FGEVMTSKLDNLIK.E (M) \\
\hline $274-285$ & 1304.53 & 1303.5247 & 1303.7024 & -0.1776 & 0 & R.EGIILDPVYTGK.A \\
\hline $286-296$ & 1252.11 & 1251.1087 & 1251.6975 & -0.5888 & 1 & K.AFYGLVDLARK.G \\
\hline $296-302$ & 760.8440 & 759.8367 & 759.4126 & 0.4241 & 1 & R.KGELGEK.I \\
\hline $321-325$ & 557.343 & 556.3357 & 557.3788 & -1.0431 & 0 & K.LLSLL.- \\
\hline
\end{tabular}

human lung (A549) and cervical (HeLa) cells. The results of the study clearly marked that only F3 fraction exerted more significant cytotoxic activity than F1 and F2 fractions against tested cell lines at concentrations ranging from $10 \mu \mathrm{g}$ $-1000 \mu \mathrm{g} / \mathrm{mL}$ as shown in Tables 2 and 3. Doxorubicin at concentrations ranging from $0.1 \mu \mathrm{g} / \mathrm{mL}$ to $10 \mu \mathrm{g} / \mathrm{mL}$ inhibited the cell proliferation of A549 and HeLa cells and served as a positive control. Untreated A549 and HeLa cells served as cell control exhibiting 100\% cell viability (Tables 2 and 3). Morphological changes consistent with apoptotic cell death were seen in A549 and HeLa cells treated with F3 isolated from seeds of B. hispida as evidenced by microscopic observations shown in Supplementary Material available online at http://dx.doi.org/10.1155/2014/179836. Cell shrinkage and rounding, were observed in A549 cells indicating 59\% cell inhibition, when treated with F3 at the concentration of
$10 \mu \mathrm{g} / \mathrm{mL}$ as given in Table 2 . Increased inhibition of cell proliferation was observed in A549 cells treated with F3 at concentrations of $30 \mu \mathrm{g} / \mathrm{mL}$ showing $78 \%$ inhibition and 100 $1000 \mu \mathrm{g} / \mathrm{mL}$ of F3 showing $>90 \%$ inhibition of cell proliferation in A549 cells as evidenced in the Supplementary Material. Further the results of MTT assay also showed that protein fraction F3 effectively suppressed the proliferation of HeLa cells with $61.38 \%$ inhibition (Table 3 ) at the concentration of $10 \mu \mathrm{g} / \mathrm{mL}$ depicting chromatin condensation (pyknosis) in the nucleus of cells undergoing apoptosis as shown in the Supplementary Material. Similar morphological alterations associated with pyknosis and karyorrhexis (nuclear fragmentation) were observed in cancer cells treated with cytotoxic proteins isolated from the various plant sources $[27,28]$. Apoptosis is an important homeostatic mechanism that balances cell division and cell death for maintaining 
TABLE 2: Percentage inhibition of A549 cells treated with different concentrations of F3 isolated from seeds of B. hispida. Cell viability was measured by MTT assay and the values are expressed as mean \pm SEM.

\begin{tabular}{lcc}
\hline Concentration $(\mu \mathrm{g} / \mathrm{mL})$ & F3 (protein fraction) & Doxorubicin control \\
\hline 10 & $59.80 \pm 6.05^{* * * *}$ & \\
30 & $78.06 \pm 4.76^{* * * *}$ & \\
100 & $89.00 \pm 4.70^{* * *}$ & \\
300 & $89.76 \pm 4.87^{* * *}$ & \\
1000 & $88.71 \pm 5.41^{* *}$ & $52.83 \pm 1.15^{* * * *}$ \\
0.1 & & $70.95 \pm 2.82^{* * * *}$ \\
0.3 & & $85.17 \pm 1.38^{* * *}$ \\
1 & & $87.35 \pm 4.33^{* * *}$ \\
3 & & $99.11 \pm 0.53^{* * *}$ \\
10 & &
\end{tabular}

$\overline{{ }^{* * * *} P}<0.0001,{ }^{* * *} P<0.001$, and ${ }^{* *} P<0.01$ indicate significant difference compared to the control. Values are analyzed by using Dunnett's Multiple Comparison Test.

TABLE 3: Percentage inhibition of HeLa cells treated with different concentrations of F3 isolated from seeds of B. hispida. Cell viability was measured by MTT assay and the values are expressed as mean \pm SEM.

\begin{tabular}{lcc}
\hline Concentration $(\mu \mathrm{g} / \mathrm{mL})$ & F3 (protein fraction) & Doxorubicin \\
\hline 10 & $61.38 \pm 2.70^{* * * *}$ & \\
30 & $68.06 \pm 5.17^{* * * *}$ & \\
100 & $99.46 \pm 0.50^{* * *}$ & \\
300 & $98.80 \pm 1.94^{* * *}$ & \\
1000 & $98.92 \pm 1.14^{* *}$ & $20.39 \pm 0.44^{* * * *}$ \\
0.1 & & $36.86 \pm 1.57^{* * * *}$ \\
0.3 & & $62.10 \pm 1.66^{* * *}$ \\
1 & & $84.89 \pm 2.98^{* * *}$ \\
3 & & $99.54 \pm 0.46^{* * *}$
\end{tabular}

${ }^{* * * *} P<0.0001,{ }^{* * *} P<0.001$, and ${ }^{* *} P<0.01$ indicate significant difference compared to the control. Values are analyzed by using Dunnett's Multiple Comparison Test.

the appropriate cell number in the body. Induction of apoptosis in cancer cells is one of the strategies for anticancer drug development $[29,30]$.

3.6. Effect of F3 on Cell Cycle of A549 and HeLa Cells. Disturbance of the cancer cell cycle is one of therapeutic targets for development of new anticancer drugs [31]. The distribution of cell population in each phase of cell cycle was examined by flow cytometry. Our results revealed that apoptosis induced by F3 fraction was not triggered at a specific phase of the cell cycle. However, F3 fraction increased the number of apoptotic cells of sub-G0 population in a time-dependent manner. Cell cycle analysis performed on A549 cells treated with F3 at a concentration of $1000 \mu \mathrm{g} / \mathrm{mL}$ for different time periods revealed interesting observations. Marked changes in the sub-G0 population (hypodiploid cells) of A549 cells were observed recording $2.11 \%$ and $2.71 \%$ increases (Table 4 ) at 24 and $48 \mathrm{~h}$ as given in the Supplementary Material. A successful anticancer compound should kill or incapacitate cancer cells without causing excessive damage to normal cells. It is evident that there is no growth in sub-G0 phase of cell cycle in control cells of both the A549 and HeLa cells which indicated the nonapoptotic population.

The most pronounced cytotoxic effect was obtained with HeLa cells treated with F3 at concentration of $1000 \mu \mathrm{g} / \mathrm{mL}$, leading to increased cell population in sub-G0 phase as $3.07 \%$ and $3.42 \%$ (Table 5) at 24 and $48 \mathrm{~h}$, indicating increased apoptotic-associated chromatin degradation in HeLa cells as shown in the Supplementary Material. Similar observations were noted with nebrodeolysin, isolated from Pleurotus nebrodensis which induced apoptosis in HeLa cancer cells [32]. The protein fraction isolated from the leaves of Mirabilis 
TABLE 4: Cell cycle analysis of A549 cells treated with protein fraction F3 (1000 $\mu \mathrm{g} / \mathrm{mL})$ from the seeds of Borreria hispida.

\begin{tabular}{lccccc}
\hline \multirow{2}{*}{ S. number } & \multirow{2}{*}{ Phases of cell cycle } & \multicolumn{2}{c}{ Control cell count (\%) } & \multicolumn{2}{c}{ Treated cell count (\%) } \\
& & $24 \mathrm{~h}$ & $48 \mathrm{~h}$ & $24 \mathrm{~h}$ & 2.71 \\
\hline 1 & Sub-G0-G1 & 0 & 0 & $52 \mathrm{~h}$ \\
2 & $\mathrm{G} 0-\mathrm{G} 1$ & 61.78 & 62.37 & 51.3 & 46.5 \\
3 & $\mathrm{~S}$ & 20.26 & 10.7 & 15.5 & 7.7 \\
4 & $\mathrm{G} 2-\mathrm{M}$ & 6.8 & 6.6 & 6.5 \\
\hline
\end{tabular}

TABLE 5: Cell cyle analysis of HeLa cells treated with protein fraction F3 $(1000 \mu \mathrm{g})$ from the seeds of Borreria hispida.

\begin{tabular}{lccccc}
\hline \multirow{2}{*}{ S. number } & \multirow{2}{*}{ Phases of cell cycle } & \multicolumn{2}{c}{ Control cell count (\%) } & \multicolumn{2}{c}{ Treated cell count (\%) } \\
& & $24 \mathrm{~h}$ & $48 \mathrm{~h}$ & $24 \mathrm{~h}$ & 3.07 \\
\hline 1 & Sub-G0-G1 & 0 & 0 & 5.42 \\
2 & G0-G1 & 61.5 & 55.43 & 59.86 & 17.04 \\
3 & S & 20.44 & 19.97 & 5.86 \\
4 & G2-M & 9.42 & 8.89 & 5.13 \\
\hline
\end{tabular}

jalapa L. was cytotoxic to HeLa cells causing DNA fragmentation and apoptosis [33]. Reports have demonstrated that the toxin abrin, a type of ribosome inactivating protein, induced cell cycle arrest and apoptotic cell death in HeLa cells [34]. Other proteins isolated from different plant sources also have been found to exhibit antiproliferation action involving cell cycle arrest in HeLa cells $[35,36]$.

\section{Conclusion}

This study is the first report of identification of the cytotoxic protein with molecular mass of $35 \mathrm{KDa}$ from the seeds of Borreria hispida showing sequence similarity with 1-325 amino acids of 1-aminocyclopropane-1-carboxylate deaminase (ACCD) of hyperthermophilic archearon, Pyrococcus horikoshii OT3. The cytotoxic protein F3 is found to exhibit growth inhibition (in vitro cytotoxicity assay) and cell cycle arrest in sub-G0 population of human lung (A549) and cervical (HeLa) cancer cells as examined by flow cytometer.

\section{Conflict of Interests}

The authors declare that there is no conflict of interests regarding the publication of this paper.

\section{References}

[1] B. R. Adriana, M. L. Rafael, and S. Gilberto, "Natural products in anticancer therapy," Current Opinion in Pharmacology, vol. 1, no. 4, pp. 364-369, 2001.

[2] S. H. Kaufmann and W. C. Earnshaw, "Induction of apoptosis by cancer chemotherapy," Experimental Cell Research, vol. 256, no. 1, pp. 42-49, 2000.

[3] J. M. Pezzuto, "Plant-derived anticancer agents," Biochemical Pharmacology, vol. 53, no. 2, pp. 121-133, 1997.

[4] H. Wenjun, C. Laiyue, Z. Guangzhi, L. D. Norelle, J. C. David, and T. Ninghua, "Isolation and characterization of cytotoxic cyclotides from Viola philippica," Peptides, vol. 32, no. 8, pp. 1719-1723, 2011.
[5] S. L. Gerlach, R. Burman, L. Bohlin, D. Mondal, and U. Göransson, "Isolation, characterization, and bioactivity of cyclotides from the micronesian plant psychotria leptothyrsa," Journal of Natural Products, vol. 73, no. 7, pp. 1207-1213, 2010.

[6] T. B. Ng, R. N. Wong, and H. W. Yeung, "Two proteins with ribosome-inactivating, cytotoxic and abortifacient activities from seeds of Luffa cylindrica roem (Cucurbitaceae)," Biochemistry International, vol. 27, no. 2, pp. 197-207, 1992.

[7] M. G. Cragg and J. N. David, "Plants as a source of anti-cancer agents," Journal of Ethnopharmacology, vol. 1, no. 100, pp. 72-79, 2006.

[8] A. J. Patel, J. R. Patel, C. P. Macwan, M. A. Patel, and A. K. Soni, "Pharmacognostical and proximate analysis of leaves of Borreria hispida," Asian Journal of Biochemical and Pharmaceutical Research, vol. 1, no. 2, pp. 157-161, 2011.

[9] K. R. Kiritkar and B. D. Basu, Indian Medicinal Plants, vol. 1, 2nd edition, 1980.

[10] K. R. Khandelwal, Practical Pharmacognosy Techniques and Experiments, vol. 157, 13th edition, 2005.

[11] S. Rupachandra and D. V. L. Sarada, "Anticancer activity of methanol extract of the seeds of Borreria hispida and Momordica dioica," Journal of Pharmacy Research, vol. 6, no. 5, pp. 565568, 2013.

[12] S. F. F. Ribeiro, O. C. Andre, D. C. Mauraha et al., "Isolation and characterization of novel peptides from chilli pepper seeds," Toxicon, vol. 50, no. 5, pp. 600-611, 2007.

[13] O. H. Lowry, N. J. Rosebrough, A. L. Farr, and R. J. Randall, "Protein measurement with the folin phenol reagent," The Journal of Biological Chemistry, vol. 1, no. 193, pp. 265-275, 1951.

[14] P. U. G. Claeson and S. Johansson, "Fractionation protocol for the isolation of polypeptides from plant biomass," Journal of Natural Products, vol. 1, no. 61, pp. 77-81, 1998.

[15] R. Secknus, G. Yamashita, S. G. Ginanni et al., "Purification and characterization of a novel human $15 \mathrm{kDa}$ cholesterol crystallization inhibitor protein in bile," Journal of Laboratory and Clinical Medicine, vol. 2, no. 127, pp. 169-178, 1996.

[16] U. K. Laemmli, "Cleavage of structural proteins during the assembly of the head of bacteriophage T4," Nature, vol. 227, no. 5259, pp. 680-685, 1970. 
[17] S. T. Kim, H. S. Kim, H. J. Kim et al., "Prefractionation of protein samples using sodium dodecyl sulfate-polyacrylamide gel electrophoresis based size fractionation for proteome analysis," Molecules and Cells, vol. 13, no. 16, pp. 312-316, 2003.

[18] W. D. Obregón, C. S. Liggieri, S. R. Morcelle, S. A. Trejo, F. X. Avilé, and N. S. Priolo, "Biochemical and PMF MALDI-TOF analyses of two novel Papain-Like plant proteinases," Protein and Peptide Letters, vol. 16, no. 11, pp. 1323-1333, 2009.

[19] M. Pascariu, A. Nevoie, D. Jitaru, E. Carasevici, and T. Luchian, "The evaluation of biological effect of cytotoxic peptides on tumor cell lines," Digest Journal of Nanomaterials and Biostructures, vol. 7, no. 1, pp. 79-84, 2011.

[20] S. I. Chuan, J. F. Tony, K. W. Tung, and H. Peng, "Anticancer and antioxidant activities of the peptide fraction from algae protein waste," Journal of Agricultural and Food Chemistry, vol. 2, no. 58, pp. 1202-1207, 2010.

[21] J. E. Hill and R. W. Breidenbach, "Proteins of soybean seeds, isolation and characterization of major components," Plant Physiology, vol. 53, no. 5, pp. 742-746, 1974.

[22] H. Kawagishi, A. Nomura, T. Mizuno, A. Kimura, and S. Chiba, "Isolation and characterization of a lectin from Grifola frondosa fruiting bodies," Biochimica et Biophysica Acta, vol. 1034, no. 3, pp. 247-252, 1990.

[23] M. E. Etzler, "Plant lectins: molecular and Biological aspects," Annual Review of Plant Physiology, vol. 36, pp. 209-234.

[24] R. Dinesh and S. Leela, "Antioxidant effects of $28 \mathrm{KDA}$ antioxidant protein from Turmeric (Curcuma longa L.)," Asian Journal of Pharmaceutical and Clinical Research, vol. 4, no. 3, pp. 119123, 2011.

[25] Z. Hao, C. Xijuan, W. Chengshang, Y. Jianzhong, and C. Hong, "Purification and characterization of a novel $18 \mathrm{KDa}$ antioxidant protein from Ginkgo biloba seeds," Molecules, vol. 17, no. 12, pp. 14778-14794, 2012.

[26] F. Aiko, O. Toyoyu, Y. Min et al., "Structural and enzymatic properties of 1-aminocyclopropane-1-carboxylate deaminase homologue from Pyrococcus horikoshii," Journal of Molecular Biology, vol. 341, no. 12, pp. 999-1013, 2004.

[27] P. L. Krishna, T. L. Vino, T. P. Vineshkumar et al., "A novel protein fraction from Sesbania grandiflora shows potential anticancer and chemopreventive efficacy, in vitro and in vivo," Journal of Cellular and Molecular Medicine, vol. 14, no. 3, pp. 636-646, 2010.

[28] A. P. Boleti, C. A. Ventura, G. Z. Justo et al., "Pouterin, a novel potential cytotoxic lectin-like protein with apoptosis-inducing activity in tumorigenic mammalian cells," Toxicon, vol. 51, no. 8, pp. 1321-1330, 2008.

[29] C. C. Shiau, R. A. David, L. Sui-Ting, L. May-Lynn, A. H. Hamid, and R. M. Mohd, "Panduratin a inhibits the growth of A549 cells through induction of apoptosis and inhibition of NFKappaB translocation," Molecules, vol. 16, no. 3, pp. 2583-2598, 2011.

[30] A. K. Taraphdar, M. Roy, and R. K. Bhattacharya, "Natural products as inducers of apoptosis: Implication for cancer therapy and prevention," Current Science, vol. 80, no. 11, pp. 1387-1396, 2001.

[31] G. K. Schwartz and M. A. Shah, "Targeting the cell cycle: a new approach to cancer therapy," Journal of Clinical Oncology, vol. 23, no. 36, pp. 9408-9421, 2005.

[32] L. V. Hui, K. Yang, Y. Qing et al., "Nebrodeolysin, a novel haemolytic protein from the mushroom Pleurotus nebrodensis with apoptosis inducing and anti-HIV effects," Phytomedicine, vol. 16, no. 2-3, pp. 198-205, 2009.
[33] I. S. Zullies, E. Widyaningsih, and P. Dyah, "Induction of apoptosis by protein fraction isolated from the leaves of Mirabilis jalapa on HeLa cells and Raji cell line," Oriental Pharmacy and Experimental Medicine, vol. 3, no. 3, pp. 151-156, 2003.

[34] Q. U. Xiaoling and Q. Liuting, "Abrin induces HeLa cell apoptosis by cytochrome c release and caspase activation," Journal of Biochemistry and Molecular Biology, vol. 37, no. 4, pp. 445-453, 2004.

[35] N. Robert, W. C. Maria, B. Wojciech, W. Danuta, B. Stanislaw, and G. J. Anna, "Cytotoxic activity of proteins isolated from extracts of Corydalis cava tubers in human cervical carcinoma HeLa cells," BMC Complementary and Alternative Medicine, vol. 10, no. 78, pp. 78-85, 2010.

[36] Z. Churiyah and S. Wahono, "Cytotoxic protein from Trichosanthes cucumerina L. var anguina (L) Haines," Biotropia, vol. 17, no. 1, pp. 8-16, 2006. 

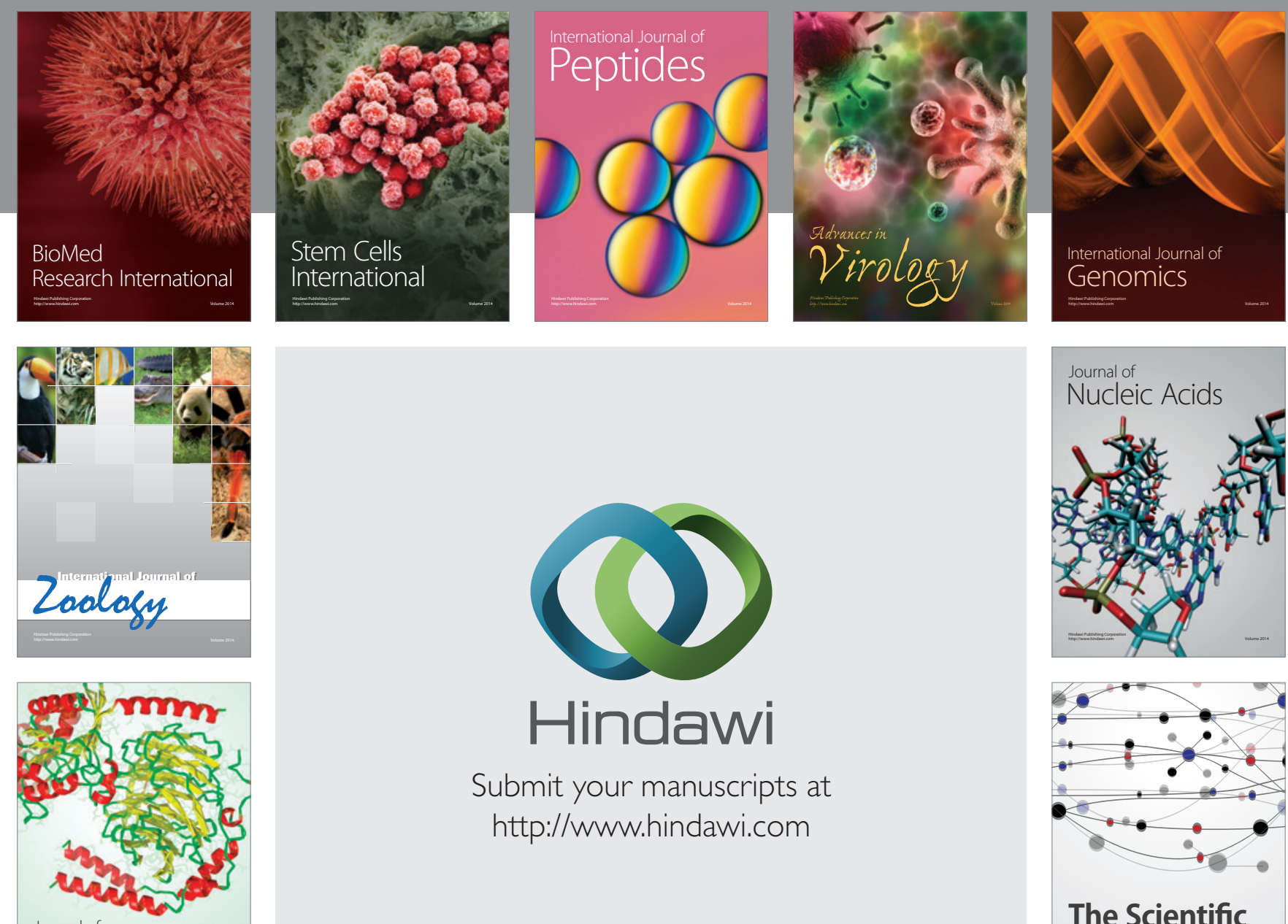

Submit your manuscripts at

http://www.hindawi.com

Journal of
Signal Transduction
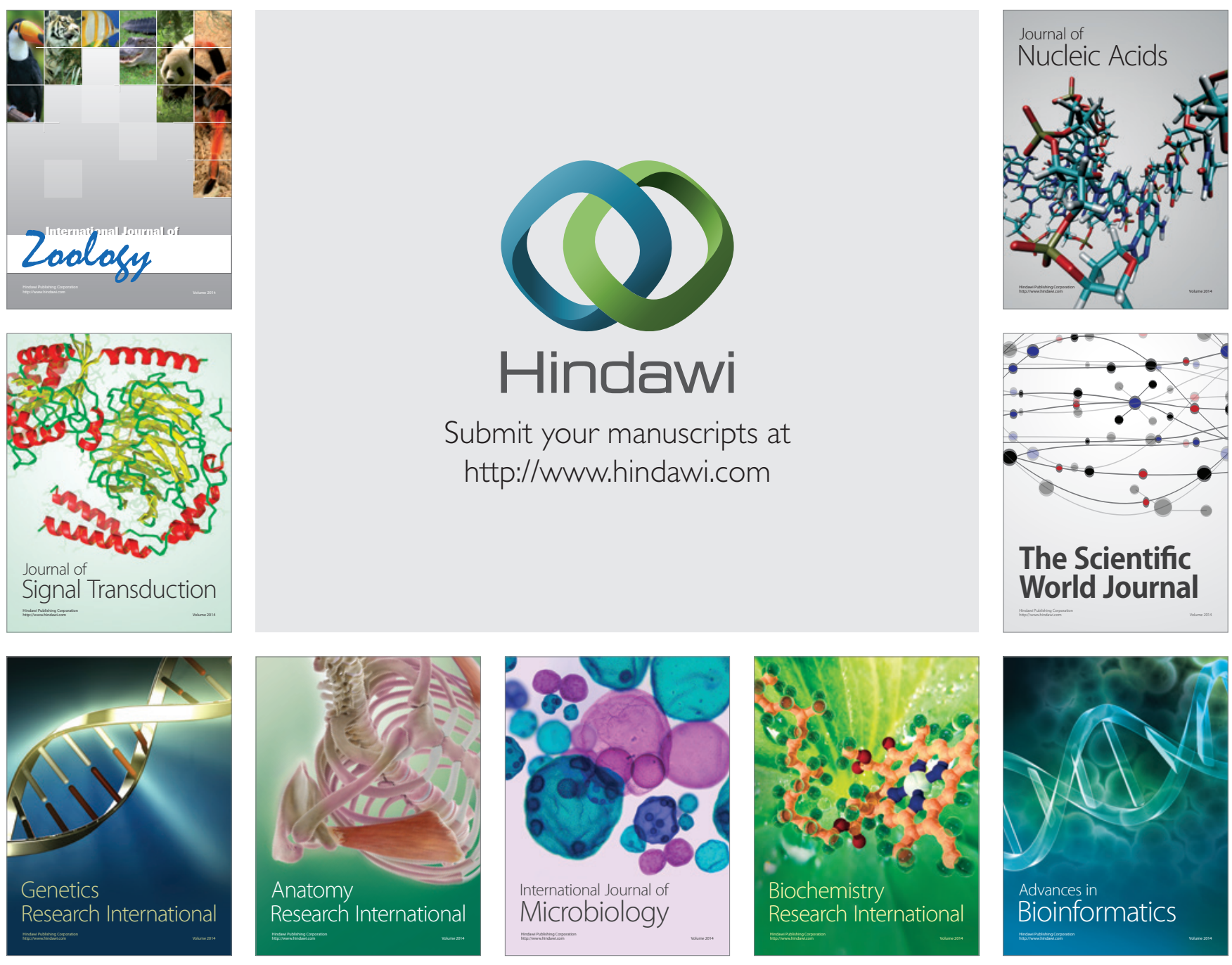

The Scientific World Journal
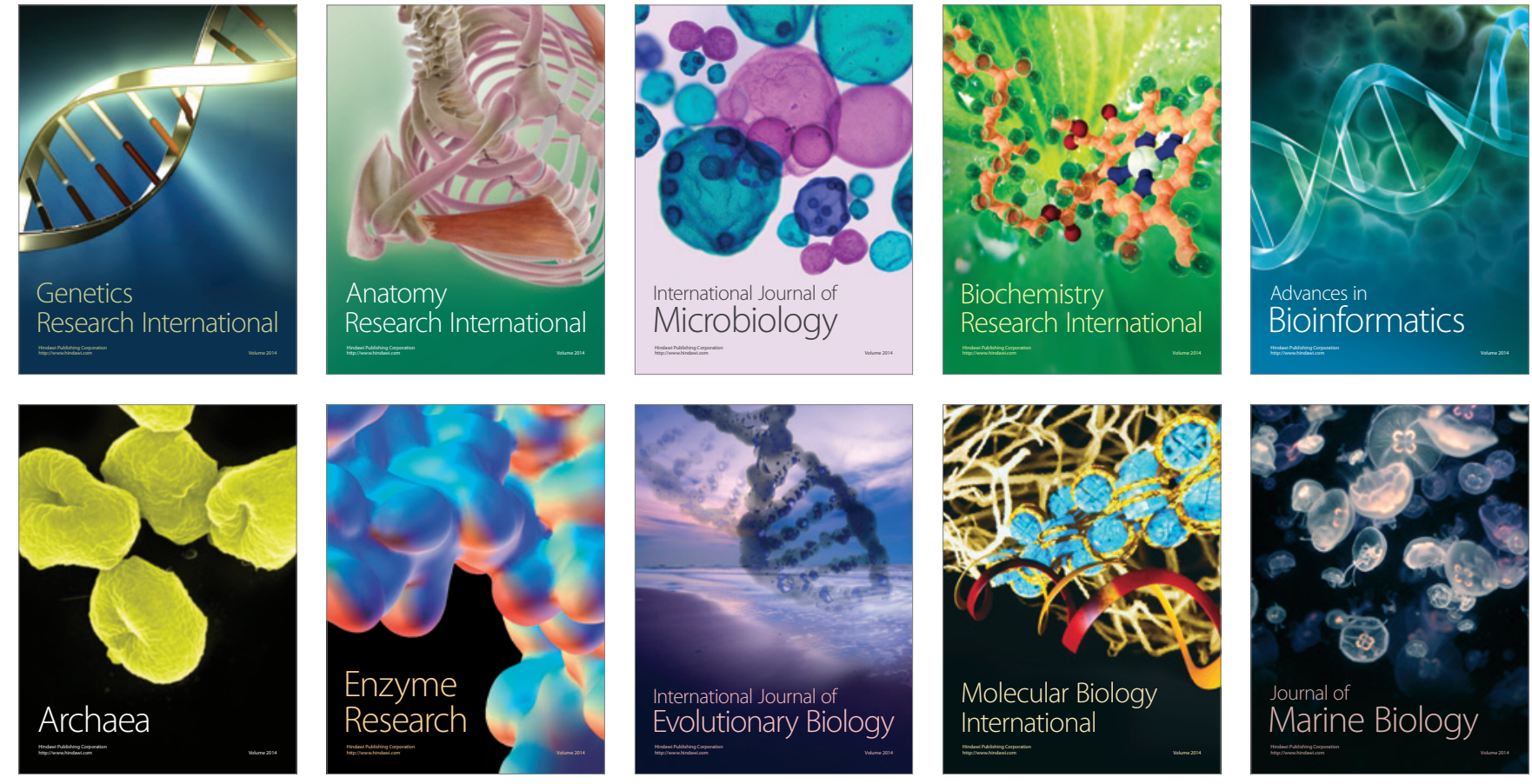